\title{
Formulation of Bacillus and Azotobacter Consortia in Liquid Cultures: Preliminary Research on Microbes-Coated Urea
}

\author{
Reginawanti Hindersah*, Mieke Rochimi Setiawati, Priyanka Asmiran, Betty Natalie \\ Fitriatin
}

Department of Soil Science, Universitas Padjadjaran, Indonesia.

*Corresponding author's e-mail: reginawanti@unpad.ac.id

How to Cite: Hindersah, R., Setiawati, M.R., Asmiran, P., and Fitriatin, B.N. (2020). Formulation of Bacillus and Azotobacter Consortia in Liquid Cultures: Preliminary Research on Microbes-Coated Urea. Int. J. Agr. Syst. 8(1): 1-10

\begin{abstract}
The spore-forming Bacillus and cysts forming Azotobacter are Plant Growth Promoting Rhizobacteria which has been used as biofertilizer in sustainable agriculture since they tolerant to dried soil. Drought resistant microbes will be useful to coat urea in order to reduce the lost of nitrogen. The objectives of this preliminary study were to study the effect of molasse based liquid media on the population of Bacillus spore and Azotobacter vegetative cell and to determine the composition of four bacterial species in liquid formula. In the first experiment The Bacillus subtilis, B. megaterium, A. chroococcum and A. vinelandii were grown separately in $1 \%$ cane molasses enriched with $0.1 \% \mathrm{NH}_{4} \mathrm{Cl}$. As control treatment, The Bacillus and Azotobacter were grown in Nutrient Broth and Ashby's mannitol broth respectively. In the second experiment, different composition of said Bacillus and Azotobacter were grown in molasses based liquid media prior to count the spore and vegetative cell. The results showed that molasses-based media supported bacterial growth and initial ratio 1:1:1:1 of liquid inoculant was effective to increase bacterial growth. This experiment suggested that the use of organic based media was useful practice of liquid biofertilizer formulation for granule urea coating.
\end{abstract}

Copyright @ 2020 IJAS. All rights reserved.

\section{Keywords:}

Liquid Biofertilizer; Spore; Bacterial Population; Molasses; Phytohormones

\section{Introduction}

Urea is an important input for agriculture, but the efficiency of urea applications is low. Coated urea is developed for slow release performance and enhance urea efficiency. Sustainable agriculture is a new approach to food production in tropical countries. This system also relies on biofertilizers which copy natural ecological processes for plant nutrition system. Drought in the upland of tropical soil has harmful impacts on agriculture so that the implementation of biofertilizer which tolerant to abiotic stress is required. Microbes-coated urea technology is considered as a simpler alternative to apply biofertilizer and urea at one time and to improve the fertilizer effectivity. The approach to prevent ammonia volatilization is to coat urea with less dissolved materials such as polymers and organic materials (Sigurdarson et al., 2018; 
Geng et al., 2016). Microbial coated urea for crop production (Ahmad et al., 2017; Wahyuni et al., 2018) is not yet widely used in Indonesia.

The Plant Growth Promoting Rhizobacteria (PGPR) Bacillus and Azotobacter form spore and cyst, respectively as natural mechanisms to adapt environmental stress (Tan and Rammurthi, 2014; Rodriguez-Salazar et al., 2017). Heat and desiccation-resistant spore formation by Bacillus and encystment of Azotobacter in dry soil allow both rhizobacteria to remain viable in drought soil. Agricultural plant inoculation with PGPR has demonstrated the useful practice of sustainable agriculture. The Bacillus and Azotobacter increased plant growth through phosphate solubilizing and nitrogen fixing mechanisms, respectively (Radhakrishnan et al., 2017; Mukhtar et al., 2018). Both bacteria have the ability to produce phytohormones and exopolysachharide (Tang et al., 2020, Malick et al., 2017; Rubio et al., 2013; Hindersah et al., 2017). Those metabolites play an important role in root development and nutrient absorption.

The commercial use of microbial biofertilizer in agriculture was usually based on single strain inoculants to perform particular activity which induce certain nutrient uptake by root system. Nowadays, Bacillus and Azotobacter have been commercialized widely, numerous single-strain biofertilizers are commercially available (Nuti et al., 2015) either in liquid or carrier-based inoculant. Liquid biofertilizer has a longer shelf life, more tolerant to of UV rays and high temperature, and higher density of microbes (Santhosh, 2017).

For commercial purposes, liquid biofertilizer formulation needs inexpensive media such as organic waste from agricultural activities. Molasses is by product from the sugarcane industry; the sugar content in cane molasses was adequate and ranged from 46-52\% (Saoud et al., 2012). Sugar might be used as carbon source and energy for heterotrophic Bacillus as well as Azotobacter. Moreover, cane molasses also contain calcium, potassium, sodium, magnesium, sulfate, sulfite, silicate, chloride, as well as aconitic, oxalic, malic, and citric acids (Torkashvnad et al., 2009; McMurray and Griffi, 2002). All inorganic substances are an important nutrient for bacterial cell growth and proliferation.

Limited information is available regarding the growth of the consortium of Bacillus and Azotobacter in liquid media. Mix culture of phosphate solubilizng bacteria and nitrogen fixing bacteria are essential to improve phosphorus $(\mathrm{P})$ and nitrogen $(\mathrm{N})$ availability in soil. Nitrogen and $\mathrm{P}$ deficiency in tropical soil are the main difficulty in increasing crop production. The use of microbial consortia might increase the efficiency of crop production, particularly under harsh environmental conditions (Bradácová et al., 2019). The objectives of this preliminary study were to verify the effect of molasses-based liquid media on the growth of Bacillus and Azotobacter and to determine the composition of four bacterial species in a liquid formula.

\section{Materials and Methods}

\subsection{Bacterial Species}

The Bacillus megaterium, B. subtilis, A. chroococcum and A. vinelandii are belong to Soil Biology Laboratory, Faculty of Agriculture Universitas Padjadjaran isolated from corn rhizosphere. The Bacillus and Azotobacter were maintained on nutrient agar (HiMedia M001, Mumbai) and Ashby's Mannitol Agar (HiMedia M706, Mumbai) respectively. Nutrient agar contained $5 \mathrm{~g}$ Peptone, $5 \mathrm{~g}$ Sodium chloride, $1.5 \mathrm{~g}$ peptone, $1.5 \mathrm{~g}$ Yeast extract, $15 \mathrm{~g}$ Agar. The composition of Ashby's media was $20 \mathrm{~g}$ Mannitol, $0.2 \mathrm{~g}$ 
Dipotassium phosphate, $0.2 \mathrm{~g}$ Magnesium sulphate, $0.2 \mathrm{~g}$ Sodium chloride, $0.1 \mathrm{~g}$ Potassium sulphate, $5 \mathrm{~g}$ Calcium carbonate, $15 \mathrm{~g}$ Agar. The bacteria were sub-cultured on agar plate at $30^{\circ} \mathrm{C}$ for $48 \mathrm{~h}$ (Fig. 1), and the free colony was transferred onto agar slant at $30^{\circ} \mathrm{C}$ for $72 \mathrm{~h}$ before the use.



B. megaterium

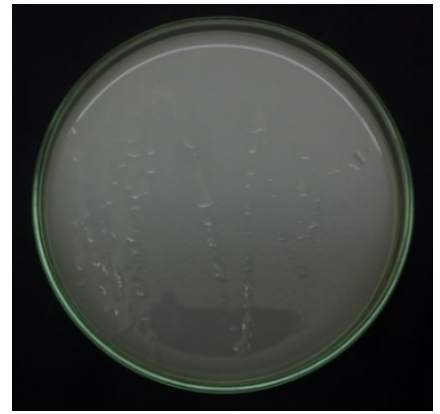

A. chroococcum

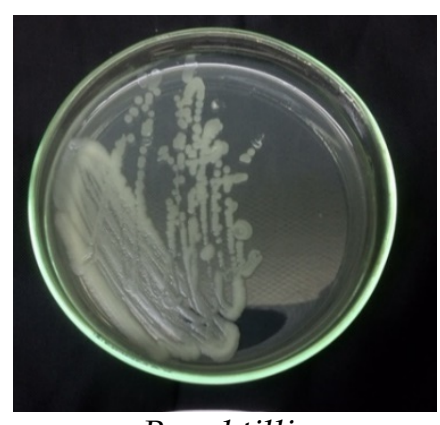

B. subtillis



A. $\quad$ vinelandii

Fig 1. Colony morphology of said Bacillus in nutrient agar plate and Azotobacter in Ashby's plate

Table 1 showed that Bacillus and Azotobacter produced exopolysachharide, phytohormone auxin (IAA), cytokinin (CKs) and gibberellines (GAs). Phosphatase that is important for mineralizing organic phosphate was detected in liquid culture of Bacillus; and both Azotobacter species fixed nitrogen as indicated by their nitrogenase activity (Table 1).

Table 1. Characteristics of Bacillus and Azotobacter as Plant Growth Promoting Rhizobacteria

\begin{tabular}{lllllll}
\hline Bacteria & $\begin{array}{l}\text { EPS } \\
(\mathrm{g} / \mathrm{L})\end{array}$ & $\begin{array}{l}\text { Phosphatase } \\
(\mathrm{mg} / \mathrm{L})\end{array}$ & $\begin{array}{l}\mathrm{IAA}^{*} \\
(\mathrm{mg} / \mathrm{L})\end{array}$ & $\begin{array}{l}\mathrm{CKs} \\
(\mathrm{mg} / \mathrm{L})\end{array}$ & $\begin{array}{l}\mathrm{GAs} \\
(\mathrm{mg} / \mathrm{L})\end{array}$ & $\begin{array}{l}\text { Nitrogenase } \\
\text { acitvity } \\
(\mathrm{nmol} / \mathrm{g} / \mathrm{h})\end{array}$ \\
\hline B. megatorium & 8.6 & 0.30 & 1.08 & 0.57 & 0.31 & - \\
B. Subtilis & 10.8 & 0.18 & 0.96 & 0.85 & 0.56 & - \\
A. Chroococcum & 6.4 & - & 0.52 & 0.97 & 0.41 & 74.1 \\
A. vinelandii & 5.9 & - & 0.82 & 0.46 & 0.35 & 65.2 \\
\hline
\end{tabular}




\subsection{Bacterial Growth Assay on molasses-based Liquid Media with Ammonium Chloride}

The Bacillus and Azotobacter have been grown in molasses-based media and specified chemical media. All bacteria were grown in 1\% cane molasses broth enriched with $0.1 \%$ ammonium chloride. As control treatments, Bacillus and Azotobacter were grown in Nutrient Broth and Ashby's mannitol broth respectively. All treatments were replicated three times.

A total of $100 \mathrm{~mL}$ of different medium were poured into $250 \mathrm{~mL}$ Erlenmeyer flask and autoclaved for 20 minutes. One agar slant of each pure bacterial culture was suspended in $10 \mathrm{~mL}$ sterilized $0.85 \%$ sodium chloride before use. Liquid media was inoculated with $0.1 \%$ pure bacterial culture, placed on gyratory shaker of $115 \mathrm{rpm}$, and incubated for 7 days at room temperature.

The Bacillus spores and Azotobacter cells were counted at day 3, 6, and 9. Enumeration of viable Bacillus spore was carried out by serial dilution method on Nutrient Agar Plate after heating the bacterial suspension at $75^{\circ} \mathrm{C}$ for 10 minutes. Counting of $\mathrm{N}$ fixing Azotobacter were performed in the by serial dilution method on N-free Ashby's medium (Widati et al., 2015)). The media which increase Bacillus spore and Azotobacter cell will be used in second experiment.

\subsection{Growth of Bacillus and Azotobacter Consortia in Molasses-based liquid media}

Based on the first experiment, molasses-based media enriched with ammonium chloride was increased Bacillus spores and Azotobacter cell and will be used in the second experiment. All bacteria were grown individually in molasses-based media said in first experiment. A total of $0.1 \%$ and $1 \%$ of mother liquid inoculant was mixed with $700 \mathrm{~mL}$ of molasses-based liquid media in 2L Erlenmeyer flask at room temperature for 72 hours on 115 rpm gyratory shaker.

The Bacillus megaterium, B. Subtilis, A. chroococcum, and A. vinelandii liquid inoculants were then mixed with the volume ratio of 1:1:1:1; 1:1:2:2; and 2:2:3:3 to final volume of $100 \mathrm{~mL}$. The $0.1 \%$ and $1 \%$ of bacterial mixed culture then each transferred to $250 \mathrm{~mL}$ Erlenmeyer flask with three replications. All cultures were incubated for 9 days in room temperature on $115 \mathrm{rpm}$ gyratory shaker. The Bacillus spore and Azotobacter cell count were performed at by 3, 5 and 7 by Serial Dilution Plate Method on nutrient agar for Bacillus and Ashby's Mannitol Agar for Azotobacter. The best composition then stored for 28 days at room temperature prior to acidity, electrical conductivity, E. coli and Salmonella population, and phytohormone production.

Prior to statistical analysis, log transformation was applied to all bacterial population data. The population density in the first and second experiment was analyzed using Duncan's multiple range test $(\mathrm{p}<0.05)$.

\section{Results and Discussion}

\subsection{Viability of Bacteria in Molasses-Based Liquid Culture with Ammonium Chloride}

The viable spore of Bacillus after heating the culture at $75^{\circ} \mathrm{C}$ for 10 minutes reached $10^{9}$ $1010 \mathrm{CFU} / \mathrm{mL}$ in agar plate; the spore population was increased from day 3 to day 9 irrespective of growth media (Table 2). Statistical analysis showed that at 9-day incubation, nutrient broth media more support the growth of bacterial spores compared to molasses, but the acidity of Bacillus liquid culture in the nutrient broth 
was 8.76 and 7.82 for B. subtilis and B. megaterium respectively. In contrast the acidity of molasses-based culture was 5.3. High $\mathrm{pH}$ of media might have inhibited Bacillus growth due to less tolerance to alkalinity. Koni et al. (2017) stated that B. subtilis proliferate optimally in the medium with acidity of 5.5.

Table 2. Spore population of Bacillus in molasses and nutrient liquid media after 9-day incubation

\begin{tabular}{lccc}
\hline \multirow{2}{*}{ Growth Media } & \multicolumn{3}{c}{ Bacillus Spore Population $\left(10^{5} \mathrm{CFU} / \mathrm{mL}\right)$} \\
\cline { 2 - 4 } & Day 3 & Day 6 & Day 9 \\
\hline Molasses 1\% + NH4Cl + 0,1\% BS & 4.3 & $530 \mathrm{~b}$ & $35,500 \mathrm{~b}$ \\
Molasses 1\% + NH4Cl + 0,1\% BM & 6.7 & $940 \mathrm{a}$ & $87,000 \mathrm{~b}$ \\
Nutrient Broth BS & 9.0 & $430 \mathrm{~b}$ & $465,000 \mathrm{a}$ \\
Nutrient Broth BM & 1.4 & $390 \mathrm{~b}$ & $210,000 \mathrm{a}$ \\
\hline
\end{tabular}

Values in a column followed by the same letter were not significant based on Duncan's multiple range test $(\mathrm{p}<0.05)$. BS: B. Subtilis, BM: B. megaterium.

The population of Azotobacter at 9-day incubation did not depend on growth media, but Table 3 clearly showed that at day 3 the population of Azotobacter in molassesbased liquid culture of $A$. chroococcum was higher than A. vinelandii. Moreover, at day 9 the population of Azotobacter in all media were not differ.

Table 3. Count of Azotobacter colonies molasses and nutrient liquid media after 9-day incubation

\begin{tabular}{lccc}
\hline \multirow{2}{*}{ Growth Media } & \multicolumn{3}{c}{ Azotobacter Population $\left(10^{3} \mathrm{CFU} / \mathrm{mL}\right)$} \\
\cline { 2 - 4 } & Day 3 & Day 6 & Day 9 \\
\hline Molasses 1\%+ $\mathrm{NH}_{4} \mathrm{Cl}+0,1 \% \mathrm{AC}$ & $14.2 \mathrm{a}$ & $465 \mathrm{a}$ & $60,000 \mathrm{a}$ \\
Molasses $1 \%+\mathrm{NH}_{4} \mathrm{Cl}+0,1 \% \mathrm{AV}$ & $1.6 \mathrm{~b}$ & $40.5 \mathrm{~b}$ & $11,625 \mathrm{a}$ \\
Ashby A. chroococcum & $5.1 \mathrm{~b}$ & $210 \mathrm{a}$ & $15,000 \mathrm{a}$ \\
Ashby A. vinelandii & $6.2 \mathrm{~b}$ & $80 \mathrm{~b}$ & $17,500 \mathrm{a}$ \\
\hline
\end{tabular}

Values in a column followed by the same letter were not significant based on Duncan's multiple range test $(\mathrm{p}<0.05)$. AC: A. chroococcum, AV: A. vinelandii

The main substance of molasses was sugar, mainly sucrose, as well as macro- and micronutrients (Torkashvnad et al., 2009). Sugar is very essential for heterotrophic bacterial growth, such as Bacillus and Azotobacter. Inorganic substance, along with the sugar in molasses, showed prominent role in cell growth and proliferation. To obtain the energy through aerobic metabolism, Azotobacter spp. use glucose, sucrose, and mannitol s carbon sources (mukhtar et al., 2018); while Bacillus capable of using many type of carbohydrates as single sources of carbon and energy (Stülke and Hillen, 2000).

\subsection{Bacterial Viability in Different Composition of Bacillus and Azotobacter Species}

The Bacillus spore population, as well as Azotobacter population in molasses-based liquid culture consortia, were not depend on bacterial composition and initial inoculant concentration (Fig. 2). The spore population in all composition irrespective of initial inoculant concentration was increased from day 3 to day 7 . In contrast, the 
population of Azotobacter in any composition with $1 \%$ initial liquid inoculation was slightly decreased from day 3 to day 5 , but increased from day 5 to day 7 .



Bacillus spore

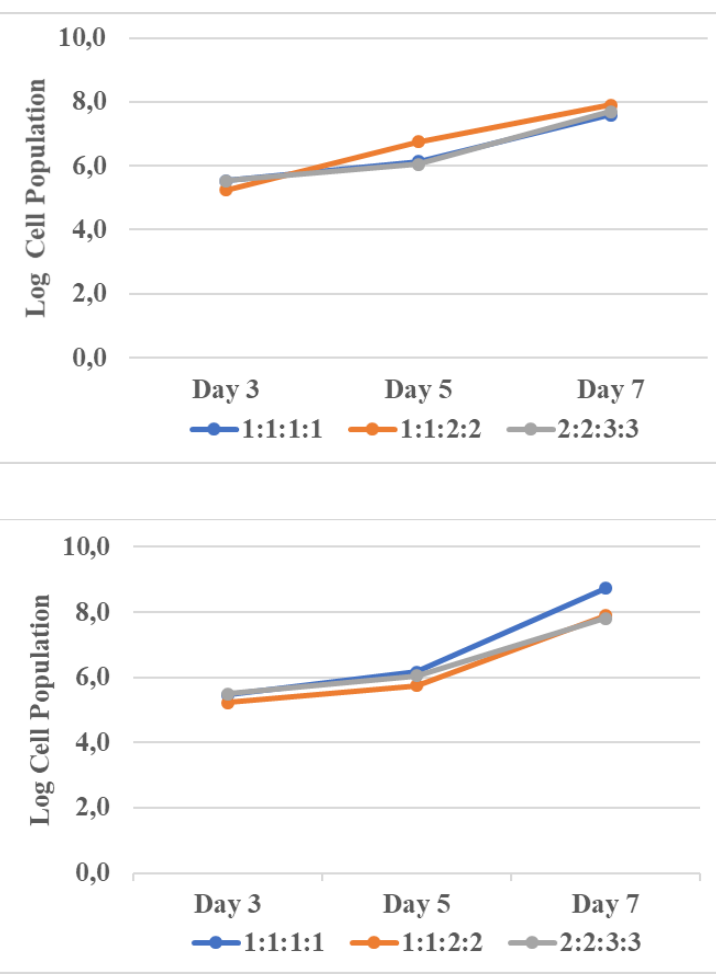

Azotobacter vegetative cell

Fig 2. Bacillus spore population (left) and Azotobacter cell population (right) at the different compositions of $B$. subtilis, B. megaterium, A. chroococcum and $A$. vinelandii with initial inoculant concentration of $0.1 \%$ (above) and 1\% (below) during 7-day incubation in molasses-based broth.

The count of Bacillus spore of all composition was up to $1010 \mathrm{CFU} / \mathrm{mL}$ in plate agar; while Azotobacter population reached $10^{8} \mathrm{CFU} / \mathrm{mL}$. For the purpose of efficiency, equal composition of the four bacterial species has been chosen to store for 28 days before inoculant properties determination as well as spore and Azotobacter population count. The increase of Bacillus spore was consistent with Azotobacter cells. The growth of both bacteria in molasses-based broth is in accordance with the curve growth of Azotobacter in similar liquid culture at room temperature for 8 days (Alami et al., 2017). However, in the contrary, the biomass of and curve growth of Bacillus has been declined at 10 hours after inoculation in chemical media enriched with molasses (Shasaltaneh et al., 2013).

In the harsh conditions, the Bacillus form spore (Tan and Rammurthi, 2014), while Azotobacter synthesize the cysts (Rodriguez-Salazar et al., 201. Molasses was the only source of carbon in our experiment, but ammonium chloride was added as nitrogen source. At 7 days, the composition of liquid culture might have to change due lower nutrient content and higher cell exudates in limited salts and mineral for bacterial growth. This circumstance induce both bacteria to form resting spores that germinated while plating in the agar media. 


\subsection{Phytohormones in Liquid Biofertilizer Consortia}

The second experiment showed that three bacterial compositions of 1:1:1:1 (v/v) might be used to develop liquid biofertilizer consortium since the population of four bacteria after 7-day incubation did not differ significantly (Fig 2). For determine the properties of said composition, liquid biofertilizer was stored for a month in room temperature $\left(24-27^{\circ} \mathrm{C}\right)$.

After one-month storage, analysis of phytohormones by using HPLC showed that bacterial composition and initial bacterial concentration induced the production of gibberellin, kinetin and zeatin (group of cytokinins) and indole acetic acid (Table 3). Phytohormone biosynthesis by rhizosphere microbes might be excreted out of the microbial cell and go through root cells (Wong et al., 2015). The microbial as well as plant phytohormones are known to affect growth processes and defense against environmental stress. According to Patel and Saraf (2017), the presence and amount of IAA, gibberellin and cytokinin are depended on the microbial species and even strain.

Cane Molasses was reported elsewhere to be an efficient and effeective carbon source for bacterial growth (Shasaltaneh et al., 2013; Alami et al., 2017; Riddech, 2019). The trytophane in the molasses was an indole precursor by which the bacteria synthesize IAA (Shasaltaneh et al., 2013). The results showed that along with IAA, other phytohormones has been detected (Table 4) which is verified that cane molasses were suitable industrial waste for producing liquid organic fertilizers (Riddech, 2019).

Table 4. Phytohormones in molasses-based liquid culture with different bacterial composition

\begin{tabular}{ccccc}
\hline $\begin{array}{c}\text { Mother culture initial concentration of } \\
\text { some bacterial composition* }\end{array}$ & $\begin{array}{c}\text { Gibberellin } \\
(\mathrm{mg} / \mathrm{L})\end{array}$ & $\begin{array}{c}\text { Kinetin } \\
(\mathrm{mg} / \mathrm{L})\end{array}$ & $\begin{array}{c}\text { Zeatin } \\
(\mathrm{mg} / \mathrm{L})\end{array}$ & $\begin{array}{c}\text { IAA } \\
(\mathrm{mg} / \mathrm{L})\end{array}$ \\
\hline $1 \%(1: 1: 1: 1)$ & 0.53 & 9.25 & 0.14 & 23.86 \\
$1 \%(1: 1: 2: 2)$ & 0.69 & 1.17 & 0.85 & 26.30 \\
$1 \%(2: 2: 3: 3)$ & 0.51 & 1.89 & 0.40 & 21.60 \\
$0.1 \%(1: 1: 1: 1)$ & 0.80 & 1.18 & 0.14 & 25.51 \\
$0.1 \%(1: 1: 2: 2)$ & 0.65 & 2.73 & 0.14 & 25.75 \\
$0.1 \%(2: 2: 3: 3)$ & 0.46 & 3.99 & 0.21 & 26.92 \\
\hline
\end{tabular}

*Composition of B. megaterium, B. subtilis, A. chroococcum and A. vinelandii by volume

The Bacillus and Azotobacter are well known phytohormone-producing rhizobacteria. Auxin produced by Bacillus sp. and in bioassay can increase the growth of potato plants (Solanum tuberosum) because auxin helps root development (Din et al., 2019; Akinrinlola et al., 2018). Azotobacter chroococcum Az d10, B. megaterium Pl-04, and B. mucilaginosus B-1574 synthesized cytokinins (CK) and indolalacetic acid (IAA), the forms of CK is dihydrozeatin riboside, isopentenyl adenosine, and trans-zeatin riboside to stimulated germination and growth (Patel and Saraf, 2017).

At the end of the experiment, all composition of liquid biofertilizer were analyzed for biological and chemical properties in relation to Ministry of Agriculture regulation for biofertilizer and organic fertilizer no 1 year 2019 (Table 5). 
Table 5. Properties of one-month-old liquid biofertilizer consortia compared with The National Regulation

\begin{tabular}{lcc}
\hline \multicolumn{1}{c}{$\begin{array}{c}\text { Average biological and chemical } \\
\text { prorties }\end{array}$} & $\begin{array}{c}\text { Liquid Biofertilizer } \\
\text { Consortium }\end{array}$ & National Regulation \\
\hline Count of Bacteria (Bacillus spore) & $>10^{10} \mathrm{CFU} / \mathrm{mL}$ & $>10^{7} \mathrm{CFU} / \mathrm{mL}$ \\
Count of Bacteria (Azotobacter) & $>10^{7} \mathrm{CFU} / \mathrm{mL}$ & $>10^{7} \mathrm{CFU} / \mathrm{mL}$ \\
Contaminant, E. coli & $<10^{3} \mathrm{MPN} / \mathrm{mL}$ & $<10^{3} \mathrm{MPN} / \mathrm{mL}$ \\
Contaminant, Salmonella & $<10^{3} \mathrm{MPN} / \mathrm{mL}$ & $<10^{3} \mathrm{MPN} / \mathrm{mL}$ \\
Acidity & 3.71 & $3.0-8.0$ \\
\hline
\end{tabular}

These results verified that the quality of one-month-old Bacillus-Azotobacter liquid fertilizer was in accordance with national regulation. Since there is no bacterial count difference between tested composition, the future research to study the shelf life of inoculant will be only performed for 1:1:1:1 composition due to practical and economical purpose.

\section{Conclusion}

Molasse-based broth enriched with ammonium chloride supported the growth of Bacillus and Azotobacter, and induced the formation of Bacillus spore which will be important to cope with drought soil. Consortia of B. subtilis, B. megaterium, A. chroococcum and A. vinenaldii in molasses-based liquid media consisted of $10^{10}$ Bacillus spore $/ \mathrm{mL}$ and $10^{8} \mathrm{CFU} / \mathrm{mL}$ of Azotobacter vegetative cell. Moreover, the liquid biofertilizer contained phytohormone Gibberellic acid, Cytokinin as well as Indole Acetic Acid. Indeed, this liquid biofertilizer properties was in accordance with The Indonesian Government Regulation about the quality of biofertilizer. This study suggested that cane molasses was a useful organic matter for biofertilizer formulation. Mixed liquid inoculant of Bacillus and Azotobacter may further be used as active ingreadient to coat granule urea. However, some experiments concerning their viability during liquid inoculant scale-up should be performed.

\section{Acknowledgements}

The funding of this research was supported by Directorate of Higher Education, Indonesia Ministry of Education year 2019. We thank to Dr. Pujawati Suryatmana from Laboratory of Soil Biology who isolated the A. vinelandii.

\section{References}

Ahmad, S., M. Imran, S. Hussain, S. Mahmood, A. Hussain, and A.M. Hasnain. (2017). Bacterial Impregnation of Mineral Fertilizers Improves Yield and Nutrient Use Efficiency of Wheat. Journal of Science Food Agriculture, 97(11): 3685-3690

Alami, N.H., S.A.T. Ayu, N.D. Kuswytasari, E. Zulaika, and M. Shovitri. 2017. Effect of Yeast Based Biofertilizer Combined with Bacteria on Mustard Plant Growth. International Journal of Applied Biology, 1(2):46-57

Bradácová, K. A.S. Florea, A. Bar-Tal, D. Minz, U. Yermiyahu, R. Shawahna, J. KrautCohen, A. Zolti, R. Erel, K. Dietel, M. Weinmann, B. Zimmermann, N. Berger, U. Ludewig, G. Neumann, and G. Posta. (2019). Microbial Consortia versus Single- 
Strain Inoculants: An Advantage in PGPM-Assisted Tomato Production?. Agronomy, 9:105

Din, E., R. Nelofer, M. Salman, Abdullah, F.H Khan, A. Khan, M. Ahmad, F. Jalil, J. U. Din, and M. Khand. (2019). Production of Nitrogen Fixing Azotobacter (SR-4) and Phosphorus Solubilizing Aspergillus niger and Their Evaluation on Lagenaria siceraria and Abelmoschus esculentus. Biotechnology Reports, 22: e00323.

Geng, J., Q Ma, J. Chen, M. Zhang, C. Li, Y. Yang, X. Yang, W. Zhang, and Z. Liu. (2016). Effects of Polymer Coated Urea and Sulfur Fertilization on Yield, Nitrogen Use Efficiency, and Leaf Senescence of Cotton Panel. Field Crops Research, 187: 87-95

Hindersah, R., O. Mulyani, and R Osok. (2017). Proliferation and Exopolysaccharide Production of Azotobacter in the Presence of Mercury. Biodiversity Journal, 8(1): 21-26

Koni, T.N.I., Rusman, Ch. Hanim, and Zuprizal. (2017). Effect of pH and Temperature on Bacillus subtilis FNCC 0059 Oxalate Decarboxylase Activity 1,2. Pak. J. Biol. Sci., 20 (9): 436-441

Malick, A., N. Khodaei, N. Benkerroum, and S. Karboune, S. (2017). Production of Exopolysaccharides by Selected Bacillus Strains: Optimization of Media Composition to Maximize the Yield and Structural Characterization. International Journal of Biological Macromolecules, 102: 539-549

McMurray, S.H. and Griffi, G.J. (2002). Extraction of Aconitic Acid from Mixtures of Organic Acids and Cane Molasses Solutions Using Supported Liquid Membranes. Chemical Technology and Biotechnology, 77(11): 1262-1268

Mukhtar, H. Hina Bashir, Ali Nawaz, IkramulHaq. 2018. Optimization of growth conditions for Azotobacter species and their use as biofertilizer. Journal of Bacteriology \& Mycology: Open Access, 6(5): 274-278

Nuti, M. and G. Giovannetti. (2015). Borderline Products between Bio-fertilizers/Bioeffectors and Plant Protectants: The Role of Microbial Consortia. Journal of Agricultural Science and Technology A, 5: 305-315

Patel T., and M. Saraf. (2017). Biosynthesis of Phytohormones from Novel Rhizobacterial Isolates and Their In-Vitro Plant Growth-Promoting Efficacy. Journal of Plant Interaction, 12: 480-487

Radhakrishnan, R., A. Hashem and E.F. Abd_Allah. (2017). Bacillus: A Biological Tool for Crop Improvement through Bio-Molecular Changes in Adverse Environments. Front Physiology, 8: 667

Riddech, N., P. Sarin, and T. Phibunwatthanawong. 2019. Effect of Bio-Liquid Organic Fertilizer on The Growth of Dipterocarpus alatus Roxb Seedlings in The Pot Experiment. Malaysian Journal of Microbiology, 15(3): 213-219

Rodriguez-Salazar, S. Moreno and G. Espín. (2017). LEA Proteins are Involved in Cyst Desiccation Resistance and Other Abiotic Stresses in Azotobacter vinelandii. Cell Stress and Chaperones, 22: 397-408

Rubio, E.J, S. Montecchia, M. Tosi, F.D. Cassán, A. Perticari and O.S. Correa. (2013). Genotypic Characterization of Azotobacteria Isolated from Argentinean soils and Plant-Growth-Promoting Traits of Selected Strains with Pospects for Biofertilizer Production. Scientific World Journal, 2013: 519603

Santhosh. G.P. (2015). Formulation and Shelf Life of Liquid Biofertilizer Inoculants Using Cell Protectants. International Journal of Researches in Biosciences, Agriculture and Technology, 2(7): 243-247 
Shasaltaneh, M.D., Z. Moosavi-Nejad, S. Gharavi, J. Fooladi. 2013. Cane Molasses as a Source of Precursors in The Bioproduction of Tryptophan by Bacillus subtilis. Iranian Journal of Microbiology, 5(3): 285-292

Sigurdarson, J.J., S. Svane and H. Karring. (2018). The Molecular Processes of Urea Hydrolysis in Relation to Ammonia Emissions from Agriculture. Reviews in Environmental Science and Bio/Technology, 17(2): 241-225)

Stülke, J. and W. Hillen. (2000). Regulation of Carbon Catabolism in Bacillus Species. Annual Review of Microbiology, 54: 849-880

Tan, I.S and K.S. Ramamurthi. (2014). Spore Formation in Bacillus subtilis. Environmental Microbiology Repository, 6(3): 212-225.

Tang, A., A.O. Haruna, N. M. Ab. Majid and M. B. Jalloh. (2020). Potential PGPR Properties of Cellulolytic, Nitrogen-Fixing, Phosphate-Solubilizing Bacteria in Rehabilitated Tropical Forest Soil. Microorganisms, 8: 442

Torkashvnad, A.M., D. Hashemabadi, B. Kaviani and S.S. Hoor. (2009). Cane Molasses: An Ammonia suppresant in the Composting Manure and Municipal Wastes. Reseach Journal of Environmental Sciences, 3(5): 567-573

Wahyuni, S., Indratin, E. Sulaeman and A.N. Ardiwinata, A.N. (2018). Activated Carbon Coated Urea Enriched with Microbial Consortia Accelerates the Decrease of Heptachlor Insecticide Residue in Paddy Fields. Informatika Pertanian, 25(2): 155 - 162 [Indonesian]

Widawati, S., Suliasih, Saefudin. (2015). Isolation and Test The Effectiveness of Plant Growth Promoting Rhizobacteria on Marginal Land on The Growth of Soybean (Glycine max L. Merr.) var. Willis. In The Proceeding of 2015 Seminar Nasional Masyarakat Diversitas Indonesia, pp: 59-65 [Indonesian]

Wong, W.S., S.N. Tan, L. Ge, X. Chen and J.W.H. Yong. (2015). The Importance of Phytohormones and Microbes in Biofertilizers. In Bacterial Metabolites in Sustainable Agroecosystem. Sustainable Development and Biodiversity, Ed., Maheshwari D. Cham: Springer, pp: 105-158 